\title{
Manure biostabilization by effective microorganisms as a way to improve its agronomic value
}

\author{
D. Hidalgo ${ }^{1,2}$ (D) F. Corona ${ }^{1,2} \cdot$ J.M. Martín-Marroquín ${ }^{1,2}$
}

Received: 27 October 2021 / Revised: 17 January 2022 / Accepted: 2 February 2022 / Published online: 10 February 2022

(c) The Author(s) 2022

\begin{abstract}
The traditional logic behind effective microorganism is based on a media inoculation with mixed cultures of beneficial microorganisms to create a more favorable environment for plant growth and health when the media is the soil. Following this rationale, other research works have been focused on studying the effect of effective microorganisms when they are used as manure stabilizing agents, in some cases by including them in animal diets, reporting, in all cases, beneficial properties. However, the use of effective microorganisms is not yet widespread. One reason may be that no rigorous research has so far been done on the actual utility of these mixed cultures on manure stabilization and crop production. In this work, the potential uses of effective microorganisms are shown with the focus on evaluating the influence of these mixed cultures on the biostabilization of manure before its use as fertilizer. This work also presents some new perspectives on the role and application of effective microorganisms as microbial inoculants to achieve a microbiological balance of manure so that it can improve its quality, increasing production and protection of crops when applied as fertilizer, helping to conserving natural resources and creating a more sustainable agriculture and environment. Finally, this document also reviews strategies on how to improve the effect of effective microorganisms after their inoculation into the soil as part of the manure.
\end{abstract}

Keywords Circular economy $\cdot$ Effective microorganisms $\cdot$ EM $\cdot$ Microbial diversity $\cdot$ Nutrient cycle $\cdot$ Biofertilisers . Animal waste

\section{Introduction}

The uniqueness of microorganisms and their often unpredictable nature and biosynthetic capabilities, depending largely on environmental conditions, have made them likely candidates to solve particularly difficult problems in different fields of science. Microorganisms have been used successfully for the past 50 years to promote environmental protection, agricultural biotechnology, and more effective treatment of agricultural and municipal waste. Many of these technological advances would not have been possible simply using chemical or physical methods, or if they were, they probably would not have been economically feasible [1]. However, while microbial technologies have been applied

D. Hidalgo

dolhid@cartif.es

1 CARTIF Technology Centre, Boecillo, 47151 Valladolid, Spain

2 ITAP, University of Valladolid, 47010 Valladolid, Spain to various agricultural and environmental problems with considerable success in recent years, they have not always been readily accepted because it is often difficult to consistently reproduce their beneficial effects. Microorganisms are effective only when they are presented with the right and optimal conditions to metabolize their substrates, including available water, nutrients, $\mathrm{pH}$, and the temperature of their environment.

The inappropriate use of animal manure and other waste streams as fertilizers has traditionally caused serious environmental and social problems around the world. Often the way to solve these problems has been using established chemical and physical methods. However, it has generally been found that such problems cannot be solved without using microbial methods and technologies in coordination with agricultural production [2, 3]. For many years, microbiologists have tended to differentiate microorganisms into harmful or beneficial according to their functions and how they affect the media in which they act [4]. When dealing with agricultural issues, beneficial microorganisms are usually considered those that can decompose organic wastes 
and residues, fix atmospheric nitrogen, detoxify pesticides, enhance nutrient cycling, suppress plant diseases and soilborne pathogens, and produce bioactive compounds that stimulate plant growth. On the other side, harmful microorganisms are those achieving the opposite effects [5].

In this scenario, a new concept arises: effective microorganisms (EM), mixed cultures of beneficial naturally-occurring organisms that can be applied as inoculants to increase the microbial diversity of an ecosystem. The concept of EM was developed in the 1980s by Higa [6] to refer to a typology of beneficial microorganisms. EM contains selected species of microorganisms including predominant populations of lactic acid bacteria and yeasts, photosynthetic bacteria, and other types of organisms. All of these are mutually compatible with one another and can coexist in liquid culture. The rationale behind the interest of EM is that inoculating a medium with mixed cultures of beneficial microorganisms can create a more favorable environment for microorganisms or living organisms already present.

Research has shown that inoculating the soil-plant ecosystem with EM, soil quality and health can improve, as well as crop quality, yield, and growth [5]. One of the reasons found for these effects is that photosynthetic bacteria, the main components of EM, are reported to work synergistically with other microorganisms to support the nutritional requirements of plants and reduce the incidence of pathogenic microorganisms [7]. Olle and Willians [8], studied the effect of EM when applied to soil on growth, yield, quality, and protection of vegetables, stated that $70 \%$ of published studies on this issue concluded that EM had a positive effect on growth of plants. The same authors concluded in another paper [9] that EM interact with the soil-plant ecosystem to suppress plant pathogens and agents of disease, to solubilize minerals, to conserve energy, to maintain the microbialecological balance of the soil, to increase photosynthetic efficiency, and to fix biological nitrogen.

Following this rationale, other research works have been focused on studying the effect of EM when they are included in animal diets. It has been shown that these EM, when they come into contact with the organic matter that makes up the animal's diet, secrete beneficial substances such as vitamins, organic acids, chelated minerals, and antioxidants [10]. The presence of EM generates also an increase in the production of short-chain fatty acids, which reduces the $\mathrm{pH}$, exerting an antibacterial effect through a selective blocking of pathogen colonization (adhesion) [11]. The use of EM in animal production is promising since different studies found an advantage regarding the repression of the growth of pathogenic organisms with antibiotics. On the other hand, they do not generate chemical residues that could be transmitted to humans [12]. Safalaoh et al. [13] studied the potential role of EM as an alternative to antibiotics in broiler diets, founding positive results with the EM effects more pronounced at the higher dosage $(30 \mathrm{~g} / \mathrm{kg})$. The absence of antibiotics in the diet reduces the environmental impact of the manure generated (free of these chemicals), and improves its potential properties as an organic amendment. Reszka et al. [14] developed a similar study with pigs, concluding that EM supplementation resulted in an increase in the protein content of the meat, which translates into better utilization of dietary nutrients that are transferred to the meat rather than to the manure, improving the economics and sustainability of the livestock rearing process. Razak [15] found that EM promoted fast growth performance in female goats and also lowered the worm burden in the animal and, consequently, in the manure. Ballena [16], in a study with laying hens, concluded that the application of EM in feeds improved production and economic parameters in hen farms, becoming a viable alternative in poultry production. Similar conclusions were obtained is studies carried out with pigs [17].

The use of EM during composting is also considered a highly efficient practice, since it favors the production of different enzymes that results in a better degradation rate of the feedstocks [18]. It is mainly indicated in the composting of slow decomposition waste, such as waste with a high $\mathrm{C} / \mathrm{N}$ ratio (woody parts of the plant, straws), grasses and fats [19]. Not only the feedstock used, but also the microbiota involved in the process totally influence the quality of the compost produced [20]. The addition of EM to the substrate promotes organic degradation in the composting process by releasing hydrolytic enzymes that break down complicated structured molecules, forming water-soluble compounds [21]. Microbial also influence on nutrients (mainly nitrogen) conservation [22]. In addition to metabolizing organic compounds, EM produce simple plant-usable compounds that improve agricultural use and stabilize the natural ecosystem when added to the soil [18]. Table 1 summarizes previous experiences of EM addition to different waste streams, resulting in accelerated composting with higher nutrient retention and an increment of potential biogas in the anaerobic digestion.

Some researchers have gone one step further in the study of potential uses for EM evaluating the potential role of $\mathrm{EM}$ on the biostabilization of manure before its use as a fertilizer. EM possess several useful characteristics in processes of stabilization of animal manure, among which are the fermentation of organic matter without the release of bad odors and its ability to convert toxic components $\left(\mathrm{H}_{2} \mathrm{~S}\right)$ into non-toxic substances $\left(\mathrm{SO}_{4}\right)$ [55]. This review discusses the most relevant research related to the nature of EM and how they influence the evolution of manure and its behavior during fertilization processes. The present review also sought to elucidate on the effects of possible mechanisms on EM linking to nutrients enrichment and beneficial effect of bioestibilized manure. It is expected that this review will be helpful in understanding the insight into the promotion of essential microorganisms in manure as well as providing a 


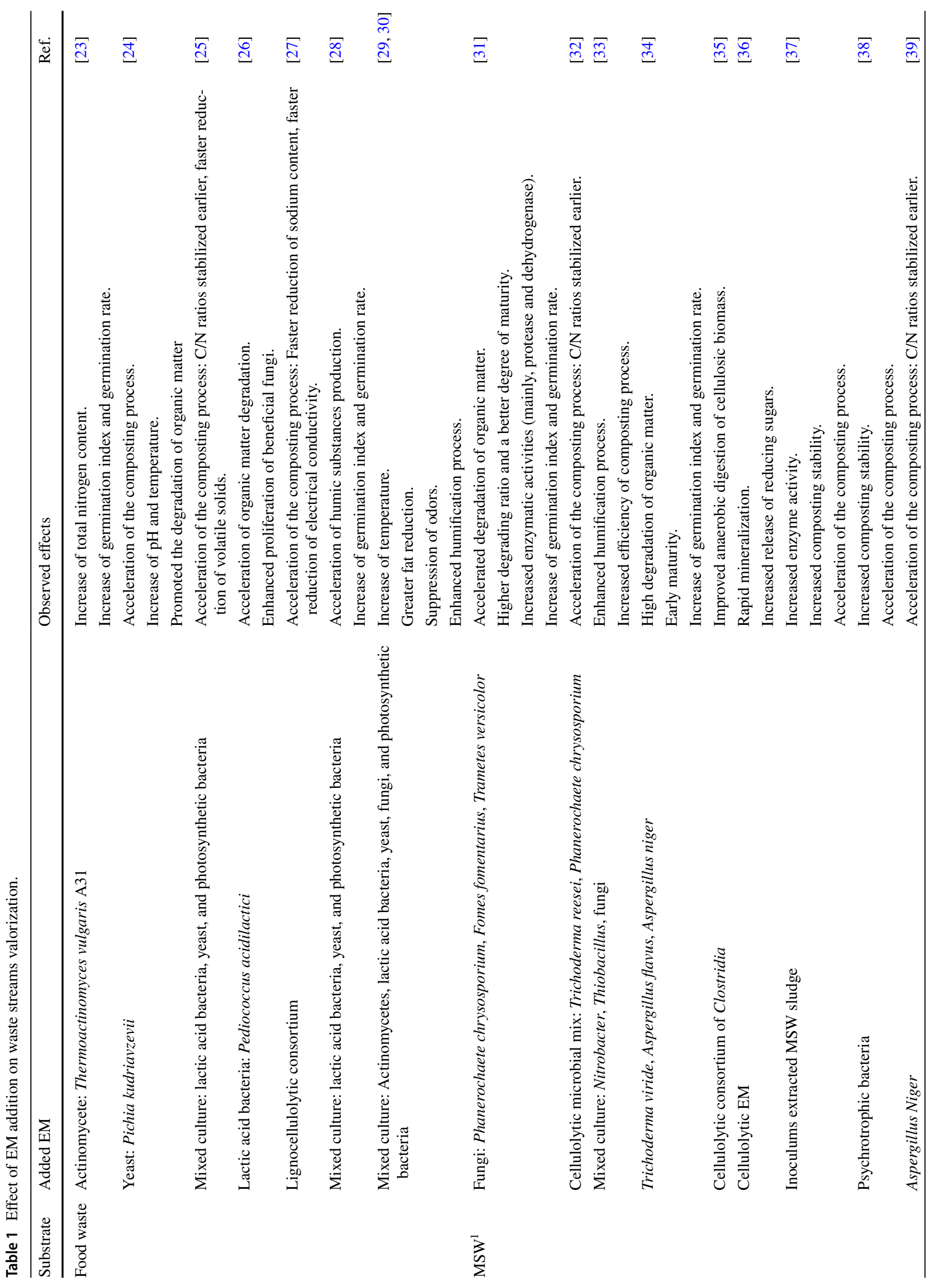




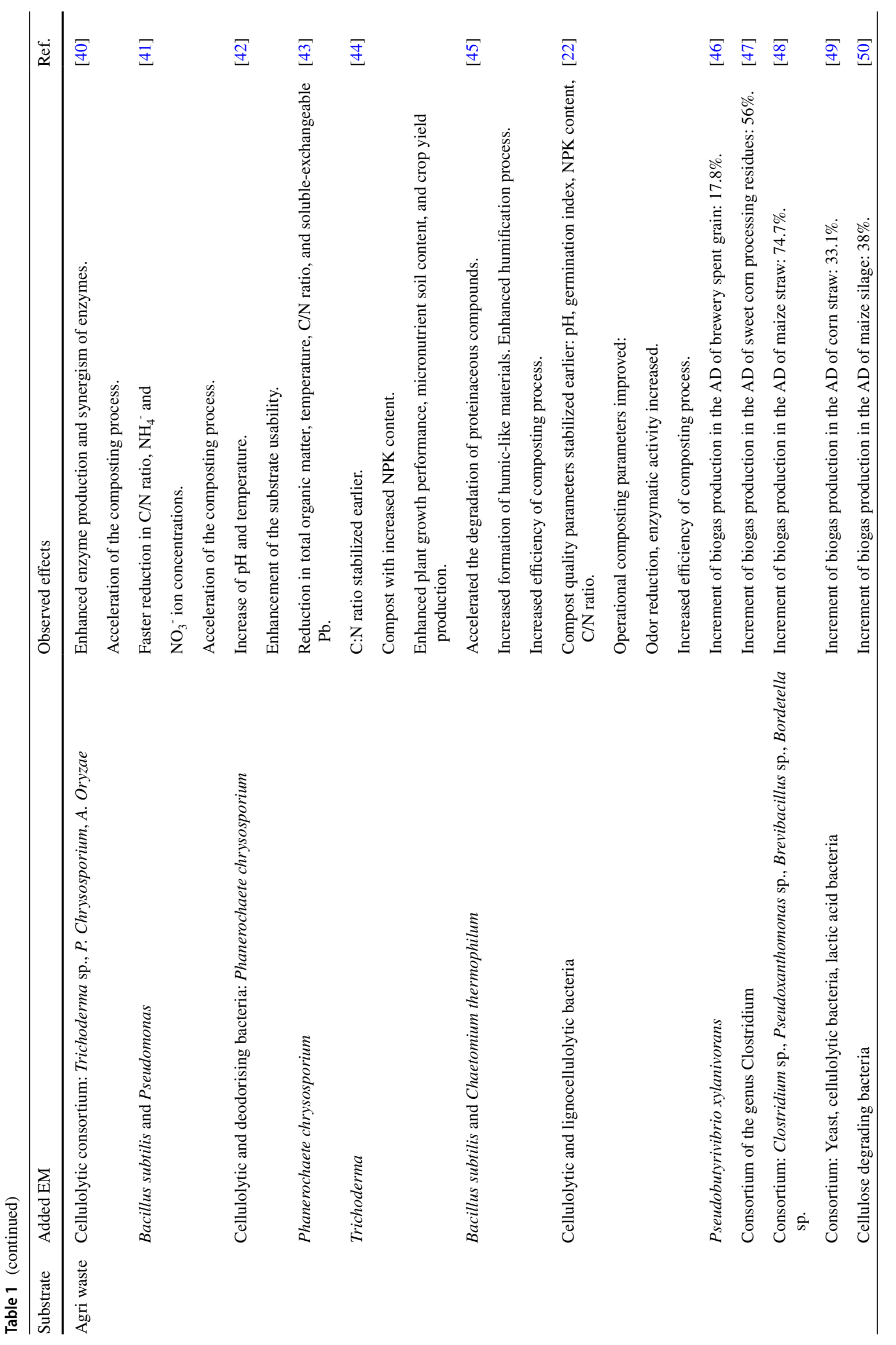


solution to further improve the presence of certain nutrients in the proper chemical form in the final products, as well as the absence of unwanted elements.

\section{Effective microorganisms}

These microorganisms are classified into large functional groups such as: photosynthetic bacteria, lactic acid bacteria, group of yeasts, group of actinomycetes and fungi. Their expected functions in the receiving environment (e.g. manure) are, among others: fixation of atmospheric nitrogen, decomposition of organic matter, suppression of pathogens, recycling and increasing the availability of nutrients for plants, degradation of toxins including pesticides, production of antibiotics and other bioactive components, production of simple organic molecules, formation of heavy metal complexes (poorly absorbed by plants), solubilization of insoluble nutrient sources, and the production of polysaccharides that can improve soil aggregation [56].

\subsection{Photosynthetic bacteria (phototrophic bacteria)}

They are a group of microorganisms mainly represented by the species Rhodopseudomonas palustris and Rhodobacter sphaeroides, facultative autotrophic microorganisms. These are independent microorganisms that synthesize bioactive substances, nucleic acids, aminoacids, and sugars from manure, used by other microorganisms, heterotrophs in general, as substrates to increase their populations [57]. More specifically, $R$. palustris is a facultative phototrophic bacterium classified as a non-sulfur purple bacterium. This species is capable of producing aminoacids, organic acids, hormones, vitamins, and sugars, where all of them can be used by heterotrophic microorganisms for their growth [56]. On the other hand, $R$. sphaeroides is a Gram-negative, facultative photosynthetic bacterium. In addition to photosynthetic activity, $R$. sphaeroides shows great metabolic diversity that includes lithotrophism, aerobic and anaerobic respiration, nitrogen fixation and the synthesis of tetrapyroles, chlorophylls, and vitamin B12 [58]. In the absence of oxygen, they prefer to get all their energy from light through photosynthesis, growing and increasing their biomass while absorbing $\mathrm{CO}_{2}$, but they can also grow by degrading toxic and nontoxic carbon compounds in the presence of oxygen. They can use the energy from infrared band of solar radiation from 700 to $1200 \mathrm{~nm}$ to produce the organic matter, while plants cannot, so the efficiency of the plants after fertilization with phototrophic bacteria enriched manure is increased [7]. The metabolites generated by these microorganisms in the manure are absorbed directly by the plants after their application and act as a substrate for the population increase of beneficial microorganisms. For example, in the rhizosphere, 
the vesicular arbuscular mycorrhizae are increased thanks to the availability of nitrogenous compounds (amino acids) that are secreted by phototropic bacteria. Mycorrhizae, in response, increase the solubility of phosphates in the soil and therefore provide phosphorus that was not previously available to plants. Mycorrhizae can also coexist with azobacter and rhizobiums, increasing the ability of plants to fix nitrogen from the atmosphere [59].

\subsection{Lactic acid bacteria}

These bacteria are acid tolerant so some can grow at $\mathrm{pH}$ values as low as 3 ; others at values as high as 9 ; and most grow at a pH between 4 and 4.5. These characteristics allow them to survive naturally in environments where other bacteria would not be able to do it [60]. This group of bacteria includes genera such as Lactobacillus (L. plantarum, $L$. casei), Lactococcus, Bifidobacterium, Streptococcus (S. lactis), and Pediococcus, which can be isolated from fermented foods or the intestinal tract of animals. These bacteria do not reduce nitrate to nitrite and produce lactic acid as the only or main product of carbohydrate fermentation [61]. Lactic acid is a powerful sterilizer. It suppresses harmful microorganisms and favors the rapid decomposition of organic matter. In addition, lactic acid bacteria enhance the breakdown of organic matter, such as lignin and cellulose, and ferment these materials, which normally take a long time [62]. Lactic acid bacteria can show an antagonistic effect against different phytopathogenic agents in manure mainly due to the decrease in $\mathrm{pH}$ and the production of peptides with antimicrobial activity, such as class I bacteriosins and nisin, highly active against Gram positive bacteria. From a bioecological point of view, these bacteria are microaerophilic, so they thrive in an atmosphere with $5 \% \mathrm{CO}_{2}$. They are slow-growing microorganisms highly dependent on temperature, whose optimum is $30^{\circ} \mathrm{C}$ [63]. Lactic acid bacteria have the ability to suppress the spread of Fusarium, which is a harmful microorganism that causes disease problems in crops [64]. There is no precise information about the way in which lactic acid bacteria act in the treatment of manures, but taking into account their characteristics, it is suggested that by lowering the $\mathrm{pH}$ an inhibition of pathogens is generated. However, not only lactic acid is responsible for the antimicrobial effects generated by lactobacilli [65].

\subsection{Yeasts}

They are a microbial group present in the preparation of EM capable of using various sources of carbon (glucose, sucrose, fructose, galactose, maltose, hydrolyzed whey, and alcohol) and energy. Several species of the genus Saccharomyces make up this microbial community, although the species Saccharomyces cerevisiae and Candida utilis prevail. These microorganisms require ammonia, urea or ammonium salts and a mixture of amino acids as a nitrogen source. They are not capable of assimilating nitrates or nitrites [66]. Other nutrients required by these microorganisms are phosphorus, magnesium (magnesium sulfate), calcium, iron, coper, zinc, and B complex vitamins [67]. These microorganisms synthesize antimicrobial substances from sugars and amino acids secreted by photosynthetic bacteria; they also produce bioactive substances such as hormones and enzymes that are substances used by lactic acid bacteria present in EM. As part of their fermentative metabolism, yeasts produce ethanol in relatively high concentrations, which is also recognized as an antimicrobial substance. It is therefore assumed that by degrading the carbohydrates present in manure, ethanol will be produced, which can function as an antagonistic substance against pathogenic microorganisms [68].

\subsection{Actinomycetes}

They are filamentous bacteria with some similarity to fungi. The growth consists of a branched mycelium that tends to fragment into bacterial elements. Many actinomycetes are free-living, particularly in the soil. They stand out for their main role in the solubilization of the cell wall or components of plants, fungi, and insects. For this reason, they are of great importance in composting and in soil formation. As components of EM, Streptomyces albus and Streptomyces griseus are the most reported actinomycete species [69]. Several species of actinomycetes, mainly those belonging to the genus Streptomyces, are excellent biological control agents due to their wide repertoire to produce antifungal compounds that inhibit the mycelial growth of various phytopathogenic fungi. The antagonistic activity of Streptomyces against pathogenic fungi is generally related to the production of antifungal compounds such as extracellular hydrolytic enzymes (chitinases and $\beta-1,3$-glucanase). They are considered important hydrolytic enzymes in the lysis of the cell walls of Fusarium oxysporum Schltdl., Sclerotinia minor Jagger, and Sclerotium rolfsii Sacc. [70]. Actinomycetes can coexist with photosynthetic bacteria. Thus, these species improve the quality of the medium on which they are added (e.g. manure), by increasing their antimicrobial activity. The central role during the degradation of manure in composting process is played by the actinobacteria. In general, the degradation of manure biopolymers is accomplished by the action of enzymes synthesized by actinobacteria such as a-amylase, glucose-isomerase, glucoamylase, and proteases [71].

\subsection{Fermenting fungi}

Fungi break down organic matter quickly to produce alcohol, esters, and antimicrobial substances, suppress odours, 
and prevent infestation by harmful insects and worms. The fungi contribute to the processes of mineralization of the organic carbon of the manure; in addition, a large number of fungi are antagonistic to phytopathogenic species. On the other hand, fungi have the ability to reproduce both sexually and asexually, where the latter allows them to multiply rapidly under favorable conditions (acidic and carbon-rich substrates) and the sexual (spores) is more common under unfavorable conditions. Fungi have relatively low nitrogen requirements, which give them a competitive advantage in the decomposition of materials such as straw and wood [72]. Among the main representatives of these fungi in EM cultures are the following species: Aspergillus oryzae (Ahlburg) Cohn, Penicillium sp., Trichoderma sp., and Mucor hiemalis Wehmer. A. oryzae is a microscopic, aerobic, and filamentous fungus. This species has been used for millennia in Chinese, Japanese, and other East Asian cuisine, especially to ferment soybeans and rice, although cellulolytic activity is also reported [58]. Several species of the genus Penicillium are excellent degradators of lignin and cellulose, very common in tropical ecosystems due to their ability to secrete extracellular enzymes, their adaptation to acidic environments and water stress, and their rapid growth [73]. The species belonging to the genus Trichoderma sp. are characterized by being saprophytic fungi, which survive in substrates with different amounts of organic matter, which are capable of decomposing it and, under certain conditions, they can be facultative anaerobes, which allows them to show greater ecological plasticity. Trichoderma species are present in all latitudes, from the polar zones to the equatorial. This wide distribution and their ecological plasticity are closely related to their high enzymatic capacity to degrade substrates, a versatile metabolism and resistance to microbial inhibitors. Trichoderma species can exert different biocontrolling mechanisms such as competition for space and nutrients, mycoparasitism, antibiosis, and resistance induction [74].

All these abovementioned microorganisms have fermentation properties, production of bioactive substances, competition and antagonism with pathogens, and help to maintain a natural balance between the microorganisms already existing in the environment, bringing positive effects on the health and well-being of the ecosystem [75]. Authors such as Ramírez [76] state that when EMs are inoculated in a medium, the individual effect of each microorganism is greatly magnified in a synergistic way by their action in the community and hence the interest in their joint application. Ramírez [763] also states that the different types of microorganisms in the EM mixture take substances generated by other organisms and base their functioning and development on this. According to Luna [56], manure contains substances that are used by these microorganisms to grow, synthesizing amino acids, nucleic acids, vitamins, hormones, and other bioactive substances. The different species of EM (phototropic bacteria, lactic acid, actynomicetes, yeasts, and fungi) have their respective functions. However, phototropic bacteria can be considered the core of EM activity. Phototropic bacteria enhance the activities of the other microorganisms. This phenomenon is called "coexistence and co-prosperity." The increase in EM populations in the soils, thanks to the addition of an enriched slurry as a fertilizer, promotes the development of beneficial microorganisms already existing in the soil. As a consequence, the soil microflora becomes abundant, and therefore, the soil develops a well-balanced microbial system. In this process, specific microbes (especially harmful ones) are suppressed, in turn reducing soil microbial species that cause disease. In contrast, in these developed soils, EM maintains a symbiotic process with plant roots next to the rhizosphere [59].

Knowledge of the types of bacteria and fungi that are part of the EM mixture added to manure and that contribute to its stabilization (through the decomposition and transformation of organic matter and nutrients and the elimination of pathogens) is essential to develop enrichment alternatives of stabilized manure or compost with a high content of nutrients in forms available to plants [77]. In many cases, microorganisms added as part of the EM mixture are classified according to the element on which they act, such as organic matter, nitrogen, phosphorus, or potassium. In this way, stabilization strategies can be designed based on the composition of the raw material to be processed, as shown in Table 2.

\section{Effects of EM on manure}

The addition of EM directly to manure seeks to establish populations of beneficial microorganisms, preventing the proliferation of other harmful ones. In this way, EM, by fermentation of the material, reduces the generation of bad odors and the presence of pest insects [59]. Recently, Hamad et al. [78] have carried out a study where have demonstrated the inhibitory role of EM on the growth of pathogenic bacteria. These authors showed how the addition of EM at low concentration (1\%) avoided the growth of pathogenic bacteria in general and S. aureus and E. coli particularly. The results of this study confirm the results of other previous studies that also showed the efficacy of EM in inhibiting the growth of pathogenic bacteria in different media. Safwat et al. [79] noted that the use of EM at concentrations of $1 \%$ and even lower had a significant inhibitory effect on the growth of ten types of pathogens (bacteria and fungi), including, in addition to $S$. aureus and E. coli, the following: Bacillus subtilis, Neisseria gonorrhoeae, Pseudomonas aeruginosa, Streptococcus faecalis, Aspergillus flavus, Aspergillus niger, Candida albicans, and Candida parapsilosis. The importance of this finding is very high given that some 
Table 2 Role and mechanisms of EM in manure biostabilization process (adapted from [77])

\begin{tabular}{|c|c|c|c|}
\hline Target element & Microorganisms & Mechanisms & Main role \\
\hline Organic matter & $\begin{array}{l}\text { Actinomicetes: } \\
\text { Streptomyces spp. } \\
\text { Thermoactinomyces spp. } \\
\text { Nocardia }\end{array}$ & $\begin{array}{l}\text { Production of phytohormones; } \\
\text { Synthesis of hydrolytic enzymes. }\end{array}$ & $\begin{array}{l}\text { Prominent role in the degradation of organic } \\
\text { matter and recalcitrant polymers such as cel- } \\
\text { lulose and lignin. } \\
\text { Active promoters of plant growth. }\end{array}$ \\
\hline Nitrogen & $\begin{array}{l}\text { Phototrophic bacteria: } \\
\text { Nitrobacter spp. } \\
\text { Nitrosomonas spp. } \\
\text { Nitrospira spp. } \\
\text { Nitrosococcus spp. } \\
\text { Nitrosolobus spp. } \\
\text { Nitrococcus spp. } \\
\text { Pseudomonas spp. } \\
\text { Xanthomonas spp. } \\
\text { Bacillus spp. }\end{array}$ & $\begin{array}{l}\text { Nitrogenase enymatic complex; } \\
\text { Ammoniamonooxygenase, } \\
\text { Nitriteoxidoreductase, } \\
\text { hydroxylamineoxidoreductase; } \\
\text { Nitrate-reductase. }\end{array}$ & $\begin{array}{l}\text { Total nitrogen fixation; organic nitrogen oxida- } \\
\text { tion; nitrate reduction. }\end{array}$ \\
\hline Phosphorus & $\begin{array}{l}\text { Fermenting fungi: } \\
\text { Penicillium spp. } \\
\text { Aspergillus } \text { spp. } \\
\text { Phototrophic bacteria: } \\
\text { Pseudomonas spp. } \\
\text { Enterobacter spp. } \\
\text { Bacillus spp. }\end{array}$ & $\begin{array}{l}\text { Production of acidic compounds (oxalic, nitric, } \\
\text { carbonic, } \mathrm{H}_{2} \mathrm{~S} \text { ); } \\
\text { Alkaline phosphatase and phytase production. }\end{array}$ & $\begin{array}{l}\text { Phosphorus solubilization; contribution to the } \\
\text { humus production; enzyme production. }\end{array}$ \\
\hline Potassium & Bacillus spp. & Secretion of polysaccharides and organic acids. & Potassium solubilization. \\
\hline Pathogens & $\begin{array}{l}\text { Lactic acid bacteria: } \\
\text { Lactobacillus spp. } \\
\text { Lactococcus spp. } \\
\text { Yeast: } \\
\text { Saccharomyces spp. } \\
\text { Candida utilis }\end{array}$ & $\begin{array}{l}\text { Production of acidic compounds (lactic acid); } \\
\text { Synthesis of antimicrobial substances (e.g. } \\
\text { ethanol); } \\
\text { Synthesis of hydrolytic enzymes. }\end{array}$ & Media sterilization. \\
\hline
\end{tabular}

of these microorganisms are characterized by their ability to cause disease in animals and humans, their resistance to antibiotics, and their environmental versatility. This is why these authors even pointed to the use of EM for disinfectant purposes. Another earlier work supporting the pathogen inhibitory character of EM is that of Rahman et al. [80]. These authors tested the effect of EM addition on four bacterial species: S. aureus, Pasteurella spp., Salmonella spp., and $E$. coli, which proved to be highly efficient in inhibiting and reducing the growth of the four bacterial species, in some cases even eliminating their presence from the culture medium. The primary role of EM in inhibiting the growth of pathogenic bacteria is not definitively determined, but it is believed to compete with pathogenic bacteria for food in the medium in which they are found [81]. In addition, the products generated in the metabolism of EM are detrimental to the growth of other bacteria, especially pathogenic bacteria, because they contain lactobacilli that produce lactic acid, which is considered a potent sterilizer that inhibits harmful bacteria [79]. In the field of animal husbandry, it is also hypothesized that EM help to maintain bacterial balance in the intestines and stimulate the immune system [82].

One of the main functional properties of EM is the fixation of atmospheric nitrogen [42]. By nitrogen fixation is meant the combination of molecular nitrogen with oxygen or hydrogen to give oxides or ammonia that can be incorporated into the biosphere. The reduction of nitrogen to ammonium carried out by free-living bacteria or in symbiosis with some plant species (legumes and some non-woody legumes) is known as biological nitrogen fixation. Within this consortium of nitrogen-fixing microorganisms, there are two large groups: the first represented by symbiotic bacteria and the second by free-living bacteria. The main symbiotic bacteria of interest are the species of the genus Rhizobium [83]. On the other hand, within the main free-living bacteria that are capable of fixing atmospheric nitrogen are the genera Azotobacter, Azospirillum, Beijerinckia, Azoarcus, Burkholderia, Enterobacter, Klebsiella, and Bacillus [84, 85]. Another interesting property of EM is the decomposition of organic matter. The process is based on the activity of the 
microorganisms that inhabit the manure that are stimulated by a high presence of these EM. The result of the joint activity is usually a stable fermented organic fertilizer, capable of fertilizing the plants and, at the same time, nourishing the soil [58].

EM also have the ability to suppress phytopathogens from manure. The use of EM consortia has proven to be efficient, for example, in the control of phytonematodes [86]. The reason is that EM can compete for space and nutrients, limiting the development of phytopathogenic species. Likewise, the suppressive activity of EM can be exerted through the production of compounds with antimicrobial activity (antibiotics and antifungal compounds), the production of siderophores, the induction of resistance, production of metabolites, antibiosis, activation of antioxidant systems in plants or the activation of resistance genes in plants [87]. EM in turn can promote nutrient recycling in manure, as well as increase nutrient availability to plants. On the other hand, these microorganisms are capable of degrading toxic agents such as pesticides, producing simple organic molecules that can be taken up by plants or forming complexes with heavy metals, which limits their uptake by the plant. The introduction into the manure of a population of beneficial bacteria has a supportive effect in reducing the microbiological diseases associated with the subsequent application of that manure to the soil. EM inoculation stimulates the "rotation effect," which occurs as a result of the elimination of pathogenic bacteria and the regeneration of beneficial organisms. Disease suppression is achieved by eliminating available resources between disease-causing microbes and beneficial microbes introduced in the soil with the EM mix, resulting in an improved population of microorganisms that will deplete available resources in manure and lead to a reduction of pathogenic microorganisms [88].

Another characteristic of EM is that they promote the solubilization of poorly soluble nutrient sources. The phosphorus compounds present in manure can be classified into inorganic and organic compounds. The mineral compounds of phosphorus usually also contain variable amounts of aluminum, iron, manganese, and calcium [89]. In many agricultural soils, large reserves of phosphorus are found in an insoluble form, due to the application of phosphorous fertilizers and, in this way, this important nutrient cannot be assimilated by the plant. Phosphate solubilizing microorganisms use different solubilization mechanisms such as the production of organic acids, which solubilize these insoluble phosphates. Soluble phosphates can already be absorbed by the plant, which improves its growth and productivity. By using these phosphate reserves present in the soils, the need to apply chemical fertilizers is also reduced. Phosphate solubilizing microorganisms can play a fundamental and practical role in improving the soil phosphorus reserve, after the addition of EM-enriched manure, without negatively disturbing the soil microflora [89]. Bacterial inoculation also shows a positive impact on the bioavailability of $\mathrm{Fe}$ in the manure, according to Joshi et al. [90]. These authors reported many applications of EM in livestock farming. For example, EM reduce unpleasant odors in farms that result from build-up of trimethylamine and ammonia. Feeding animals a ration that incorporates EM improves their internal microbiota and therefore reduces the intensity of manure odors. These authors also observed that the spraying of EM microorganisms inside the stables, as well as the addition of EM to the drinking water of the animals, improve the microbial environment of the entire barn, including the intestinal bacterial flora of the cattle, helping to avoid diseases. As a result, various beneficial effects are observed, such as that the taste and quality of the animal products improve and the products stay fresh for longer periods. In addition, it is possible to reduce the use of vaccines and antibiotics, thus supporting safer production of animal products from the point of view of both producers and consumers [90].

Focusing on livestock manures, it is well known that they are a source of a diversity of nutrients and can improve the biological, chemical, and physical characteristics of the soil. However, the effects of organic fertilizers on crop yields are long-term and not immediate, so farmers often prefer the use of mineral fertilizers in their cropping systems. The addition of EM along with organic fertilizers is demonstrated to be an effective technique to stimulate the supply and release of nutrients from plants [91]. According to Khaliq et al. [92], the application of organic residues or EM alone does not significantly increase crop yield. However, their integrated use of both products resulted in a $44 \%$ increase in yield over the control crop. Application of EM with commercial mineral fertilizer (instead of manure) resulted in a slight increase in yield (14\%) over mineral fertilizer alone, demonstrating that EM is more effective when applied with organic fertilizers. The relatively low response of mineral fertilizer compared to the application of EM is justified, according to these authors, by the fact that EM is composed of different microorganisms that can respond well only in the presence of sufficient organic matter. The following sections review the results obtained in different investigations when the EM were added to slurry of different origins to be used as a fertilizing source.

\subsection{Effects on chicken manure}

It is common practice in poultry to overfeed chickens to a minimum weight of $2 \mathrm{~kg}$ before entering the market. This practice usually results in a large generation of manure with a high protein content along with other nutrients such as minerals and carbohydrates [93]. These nutrients can be converted into a high-quality organic fertilizer through composting. Composting is a process that takes advantage 
of microbial activity to stabilize organic waste under controlled temperature, $\mathrm{pH}$, and humidity conditions. During the process, aerobic microorganisms break down biodegradable organic materials to produce a stable end product known as compost that is rich in humic acid-like substances [94]. Generally, composting manure takes a long time, such as 45 days for chicken manure [95]; however, this process can be enhanced by adding EM to the manure in the generation houses themselves, which, at the same time, has been shown to reduce the local impact of the animals due to odors, the appearance of insects and leaching [96]. Gunawan et al. [97] investigating locally available and affordable alternatives of EM achieved poultry compost maturation at day 24. In another study, Joseph et al. [98] showed that incorporation of EM into poultry manure significantly increased shoot height, stem diameter, leaf number, leaf area, and fresh leaf weight on Red amaranth (Amaranthus hybridus) crops. Furthermore, a reduced pest infestation of the manure was observed. These results were in consonance with the findings of Reddy and Giller [99] that reported successful insect control in cucurbits and legumes with the addition of EM, as well as better growth on crop leaves and stems, leading to $15 \%$ yield increases. Vegetable crops are highly susceptible to pests and diseases during the growing phase. According to Joseph et al. [98], the incorporation of EM into organic matter performs two main functions. First, it creates better growing conditions that lead to a stronger and healthier plant. Second, it inoculates the surface of the leaves with beneficial microbes, which compete with pathogens. The EM in poultry manure acts, according to these authors, as an insect repellent by creating a barrier around the plant when applied.

Wan et al. [53] studied the effects of EM inoculation in compost of chicken manure with corn straw by evaluating the influence of temperature, $\mathrm{pH}$, humidity, nitrogen transformation, $\mathrm{C} / \mathrm{N}$ ratio, humification levels, and maturity of the compost. The results showed that the inoculation with microorganisms prolonged the thermophilic stage in the composting compared to the control groups, increasing the temperature, the $\mathrm{pH}$, and the germination index as the composting period progressed. These results suggest that inoculation with microorganisms was useful to facilitate the composting process, since it significantly reduced ammonia content during the cooling stage. Furthermore, nitrate content increased on day 10, continuing until the end of the thermophilic stage. Improvements were also observed in nitrogen transformation, humification levels, and compost maturity in the inoculation piles. In conclusion, the authors suggested generalizing the practice of EM cocktail inoculation to increase efficiency and promote maturity in composting chicken manure. Uribe et al. [100] reached similar conclusions when evaluated the poultry manure composting process of cage birds and the effect of EM on the physical and chemical composition of the compost. The mixture of chicken manure with EM presented a faster decrease in $\mathrm{pH}$, below 8.5, which indicates an acceleration in the compost stabilization process. The physicochemical tests carried out by these authors showed higher values of nitrogen and potassium for the mixture of chicken manure with EM. The values in the carbon/nitrogen ratio and in the cation exchange capacity were adequate and in line with what is normally obtained for this type of composting.

\subsection{Effects on cattle manure}

Composting is a common and effective method of treating cattle manure and the resulting product can be used as organic fertilizer [101]. During the process, bacteria, fungi, microarthropods, and other organisms break down organic material into stable and usable organic substances called compost [102]. The degradation process occurs naturally; however, different measures have been developed to accelerate the biodegradability of the indigenous microbial community. Inoculation is an induced measure that helps to increase the initial microbial population in cattle manure, generate the desired enzymes, improve the number of beneficial microbial communities, and therefore significantly improve the overall composting process [103]. Jiang et al. [104] reported that adding 1\% EM (including ammonifiers, nitrobacteria, and Azotobacter) at the beginning of composting could effectively promote compost maturity and reduce nitrogen loss. Xi et al. [103] also found that the inoculation of microbes increased the content of fulvic and humic type compounds, as well as the degree of humification of the composting products. These authors reported that the multistage inoculation method extended the period of high temperature and improved the community diversity of bacteria and fungi; at the same time, it reduced competition between the inoculations and indigenous microbes, which favored the growth of the inoculated microorganisms. Zhao et al. [105] using in this case compost from agricultural waste also observed that inoculation at different stages of composting could clearly accelerate degradation and improve the diversity of the actinobacteria community. Nakasaki et al. [106] showed that the yeast strain Pichia kudriavzevii RB1 affected the early stages of cattle manure composting before the thermophilic stage and accelerated the general composting process. Li et al. [102] inoculated cattle manure with a mixture of EM isolated from natural composting piles, noting that this action did not significantly shorten composting time. However, the pile temperature increased, the degradation of organic matter accelerated, and a significantly higher germination rate indicated that maturity was promoted by the inoculating microorganism. In general, all the authors mentioned above demonstrated that the inoculation of EM in cattle manure increases the degradation of organic matter 
beyond the capacities of indigenous microorganisms, and that it is advisable to add several inoculations at multiple stages of the composting process to maximize results.

\subsection{Effect on pig manure}

The inoculation of EM in swine manure is less studied than in poultry or cattle manure, due to the high water content of this stream that hinders the economic sustainability of the process in some cases. However, it has been observed how the creation of an antioxidant environment by EM assists in the enhancement of the solid-liquid separation [107], which is the foundation of pig manure treatment. Zhou et al. [108] performed a study to investigate the effect of adding EM in the microbial community and the bioavailability of heavy metals during pig manure composting. In all the experiments the compost met the safety requirement with a germination rate of $96.42 \%$. The overall diversity of bacterial and fungal species decreased throughout the composting process. Also, the bioavailability of $\mathrm{Cu}$ and $\mathrm{Pb}$ decreased significantly during composting, detecting a correlation between this parameter and the change in the structure of the bacterial and fungal community. Li et al. [109] found that the conversion of $\mathrm{Cu}$ and $\mathrm{Zn}$ to forms with higher stability during the composting of pig manure with biochar and EM was associated with the formation of fulvic and humic acid-like substances. On the other hand, $\mathrm{Xu}$ and Li [110] studied the effects of a commercial microbial inoculant of EM on the composting of pig manure, comparing the evolution of two identical piles, under the same environmental conditions and with the only difference of that one pile was inoculated with EM and the other was not. The results showed a higher temperature increase at the beginning of composting in the inoculated pile. This pile also showed a higher content of $\mathrm{N}, \mathrm{P}_{2} \mathrm{O}_{5}, \mathrm{~K}_{2} \mathrm{O}$, and macronutrients (NPK), demonstrating that EM inoculation accelerates the transformation of the macronutrient in the final compost product. Changes in total organic carbon indicated that inoculation was also capable of accelerating the decomposition of organic carbon. At the end of composting, the value of the compost germination index that came from inoculated manure was higher than that of the control by $60 \%$. Bastami et al. [111] focused their research on the pig manure storage stage, since in this stage, microbial processes and chemical reactions result in a large release of gases such as methane, nitrous oxide, ammonia, or carbon dioxide, which contribute to the generation of unhealthy environments in the farm. These authors examined how methane emissions evolved from slurry storage under two temperatures (cold, $10{ }^{\circ} \mathrm{C}$ and warm, $30{ }^{\circ} \mathrm{C}$ ) when a $10 \%(\mathrm{w} / \mathrm{w})$ solution of EM in a substrate rich in glucose was applied. The addition of sugar influenced anaerobic microbial respiration, resulting in a reduction of the slurry $\mathrm{pH}$ to $<5.0$, through "self-acidification" caused by lactic acid production. Subsequently, $\mathrm{CH}_{4}$ emissions were significantly reduced by 87 and $99 \%$ in cold and warm environments, respectively. These results suggest that self-acidification after the addition of EMs may be a promising alternative to acidification of manure using concentrated acids. Another study [112] investigated how ammonia emissions from crude slurry were affected after the addition of different EM mixtures. In the ammonia removal efficiencies of the experimental groups, some mixed cultures showed 55.9 to $86.7 \%$ removal efficiencies throughout the period compared to the control group that had not undergone any inoculation. Other studies also show how pig manure inoculation with an EM mixture rich in lignocellulose-degrading microorganisms could decrease the risk of antibiotic resistance genes spreading and make manure management processes more secure [113].

\section{Strategies to improve the effect of EM after their inoculation into the soil}

The original uses of EM were in agriculture to increase the productivity of organic farming systems [8]. Today, EM are often applied to the soil directly as part of the organic matter added to the fields, either as manure or other fertilizer, or provided as part of a compost that has been prepared using $\mathrm{EM}$ as an additive to improve and shorten the maturation process. Research has also demonstrated that inoculation of soils with EM-inoculated manure can improve soil health and soil quality. This general improvement is often related to increased organic matter content, improved infiltration and aggregation, increased aeration, and decreased bulk density, erosion, or compaction [5]. The beneficial effects generated by EM are not immediate, but are observed when the inoculated microorganisms become established and dominant in the medium. In some soils, a single EM inoculation may be sufficient to produce the desired results, although this is not common. Most authors recommend repeated application of EM-enriched manure, especially during the first growing season, in order to facilitate earlier establishment of the introduced microbiota [8].

The application of EM-enriched manure to the soil/crop can be done in different ways, depending on the nature of the manure (solid or liquid), as discussed below:

EM inoculation directly into the soil—different EM preparations can be applied to the soil prior to sowing or during cultivation. When using EM in fermented poultry manure, Ncube [91] recommends a 1:300 dilution of EM multiplied in water. This author recommends an application of enriched compost up to 2.5 tons per hectare. Higher doses may be detrimental to plants due to the high levels of organic acids generated which may damage their roots. EM applications mix with the soil by plowing. 
Irrigation with EM-enriched liquid manure (fertigation) - EM formulations can be applied to the soil via the irrigation with manure. Dilutions of EM from 1:1000 to 1:5000 could be used [91].

Spraying EM-enriched liquid manure on leaves-spraying EM on plant leaves can serve as a pest control and prophylactic treatment for disease control. Spraying is recommended to be done periodically throughout the plant's growth period. Ncube [91] recommended dilutions of 1:1000 of EM although, depending on the culture, dilutions of 1:500 or 1:2000 could also be used.

According to Olle and Willians [8], depending on the amount of manure to be turned into humus, the required dose of EM can vary considerably between 20 and 40 liters per hectare in the case of diluted preparations up to 1-3 liters per hectare in the case of more concentrated commercial preparations. If the soil contains high levels of undecomposed organic matter, the dose of added EM can be increased. Whenever possible, it is advisable to dose EM in spring and, if an autumn treatment has not been carried out, these doses should be increased to ensure proper inoculation of the soil with EM.

\section{Conclusions and future research}

When EM increase their population, as a community in the environment in which they are, the activity of natural microorganisms increases, enriching the microflora and balancing microbial ecosystems. EM comprise a great microbial diversity represented by lactic acid bacteria, photosynthetic bacteria, yeasts, actinomycetes and filamentous fungi with fermentative activity. These microbial consortia have numerous applications in manure management, when their final use is as fertilizer, because they functionally favor the degradation of organic matter, the transformation of nutrients into forms assimilable by plants, the control of emissions and odors and the absence of pathogenic organisms. In this sense, the mixed culture EM contains anaerobic and aerobic microorganisms that cause the decomposition of organic matter. The objective of lactic bacteria is to transform part of the carbohydrates into lactic acid with a resulting effect that is the decrease in $\mathrm{pH}$ with great control of pathogenic microorganisms. Phototrophic bacteria carry out incomplete anaerobic photosynthesis, being very useful because they will be able to detoxify the manure of toxic substances for the plant that are formed during fermentation. They are also capable of conserving nitrogen during manure processing. Biostabilized manure, when applied to the soil, can progressively inhibit the attack of other bacteria and microorganisms that cause pathologies by having a colonizing effect on the soil due to the displacement produced by the space they occupy and by reducing its energy supply. The microorganisms developed in the medium after the application of the inoculated manure constitute the optimal environment for plant growth, generating a great rooting and biostimulating effect, and positively affecting the quality of the crops and the soil. All the studies gathered in this document suggest that the inoculation of EM in manure is a feasible strategy to convert animal wastes into compost efficiently, in addition to improving health conditions in livestock facilities.

Many researchers are working today to analyze the effect of EM-rich diets on animal health and welfare and on the quality of meat and eggs. In general, a change in the global metabolism of the animal is detected thanks to EM, which will undoubtedly have repercussions on the composition of the manure and its agronomic value. However, very few references have been found that analyze the quality of the manure when the animal is fed with a diet rich in EM. On the other hand, no reference has been found in which the potential of this manure enriched in EM through the diet is evaluated as fertilizer. This research is proposed now as a future line of work given its potential interest.

Author contribution D. Hidalgo had the idea for the article. All authors contributed to the literature search and data analysis. The first draft of the manuscript was written by D. Hidalgo and all authors commented and critically revised the work. All authors read and approved the final manuscript.

Funding This work is funded by European Commission through the grant agreements ID: 773682 (NUTRI2CYCLE project) and ID: 818470 (NUTRIMAN project).

Open Access This article is licensed under a Creative Commons Attribution 4.0 International License, which permits use, sharing, adaptation, distribution and reproduction in any medium or format, as long as you give appropriate credit to the original author(s) and the source, provide a link to the Creative Commons licence, and indicate if changes were made. The images or other third party material in this article are included in the article's Creative Commons licence, unless indicated otherwise in a credit line to the material. If material is not included in the article's Creative Commons licence and your intended use is not permitted by statutory regulation or exceeds the permitted use, you will need to obtain permission directly from the copyright holder. To view a copy of this licence, visit http://creativecommons.org/licenses/by/4.0/.

\section{References}

1. Kiefer D, Merkel M, Lilge L et al (2021) From acetate to biobased products: underexploited potential for industrial biotechnology. Trends Biotechnol 39(4):397-411. https://doi.org/10. 1016/j.tibtech.2020.09.004

2. Lokko Y, Heijde M, Schebesta K et al (2018) Biotechnology and the bioeconomy - towards inclusive and sustainable industrial development. New Biotechnol 40:5-10. https://doi.org/10.1016/j. nbt.2017.06.005 
3. Mehta D, Vanderschuren H (2021) Towards responsible communication of agricultural biotechnology research for the common good. Nat Rev Mol Cell Biol 22(5):301-302

4. Pandey A, Tripathi A, Srivastava P et al (2019) Plant growthpromoting microorganisms in sustainable agriculture. In: In: Role of plant growth promoting microorganisms in sustainable agriculture and nanotechnology. Woodhead Publishing, Sawston, pp 1-19

5. Higa T, Parr JF (1994) Beneficial and effective microorganisms for a sustainable agriculture and environment, vol 1. International Nature Farming Research Center, Atami

6. Higa T (1991) Effective microorganisms: a biotechnology for mankind. In: Parr JF, Hornick SB, Whitman CE (eds) Proceedings of the First International Conference on Kyusei Nature Farming. U.S. Department of Agriculture, Washington, pp 8-14

7. Cóndor AF, González P, Lokare C (2007) Effective microorganisms: myth or reality? Rev Peru Biol 14(2):315-319. https://doi. org/10.15381/rpb.v14i2.1837

8. Olle C, Williams Y (2013) Effective microorganisms and their influence on vegetable production - a review. J Hortic Sci Biotechnol 88(4):380-386. https://doi.org/10.1080/14620316.2013. 11512979

9. Olle M, Williams I (2015) The influence of effective microorganisms on the growth and nitrate content of vegetable transplants. J Adv Agric Technol 2(1):25-28. https://doi.org/10.12720/joaat.2. $1.25-28$

10. Valdéz A, García Y, Álvarez VM et al (2020) Effect of efficient microorganisms, native to Guantánamo, Cuba, on bioproductive and hematological indicators of pre-fattening pigs. Cuba J Agric Sci 54(3):365-373

11. Reszka P, Dunislawska A, Slawinska A et al (2020) Influence of the effective microorganisms (EM) on performance, intestinal morphology and gene expression in the jejunal mucosa of pigs fed different diets. J Anim Physiol Anim Nutr 104(5):1444-1453. https://doi.org/10.1111/jpn.13404

12. Abdel-Aziz M, Bessat M, Fadel A et al (2020) Responses of dietary supplementation of probiotic effective microorganisms (EMs) in Oreochromis niloticus on growth, hematological, intestinal histopathological, and antiparasitic activities. Aquac Int 28:947-963. https://doi.org/10.1007/s10499-019-00505-z

13. Safalaoh ACL, Smith GA, Senanayake YDA et al (2002) Effective microorganisms (EM) as an alternative to antibiotics in broiler diets: effect on broiler growth performance, feed utilisation and serum cholesterol. In: Department of animal and wildlife sciences. University of Pretoria, South Africa. http://www.emtur key.com.tr/eskisite/TR/dosya/1-372/h/effective-microorganismsem-as-an-alternative-to-antibi-.pdf. Accessed 18 Oct 2021

14. Reszka P, Cygan-Szczegielniak D, Jankowiak H et al (2020) Effects of effective microorganisms on meat quality, microstructure of the longissimus lumborum muscle, and electrophoretic protein separation in pigs fed on different diets. Animals 10(10): 1755

15. Razak MAA, Zakaria MZ, Tayid MAM et al (2018) Effects of diets containing effective microorganisms (EM) on growth performance, worm burden, hematological and biochemical analysis in female goats. In: Bioresources Technology in Sustainable Agriculture. Apple Academic Press, Boca Raton, pp 67-80

16. Ballena KM (2011) Efecto del uso de microorganismos eficaces (Bacterias Fototróficas, Bacterias Ácido Lácticas y Levaduras) en el alimento sobre los parámetros productivos de gallinas de postura de la línea Lohmann Brown. Doctoral Thesis. Universidad Nacional de Trujillo. https://dspace.unitru.edu.pe/handle/ UNITRU/10188. Accessed 30 Oct 2021.

17. Ojeda-García F, Blanco-Betancourt D, Cepero-Casas L et al (2016) Effect of the inclusion of a biopreparation of efficient microorganisms (IHplus $\left.{ }^{\circledR}\right)$ in diets of fattening pigs. Pastures Forages $9(2)$

18. Rastogi M, Nandal M, Khosla B (2020) Microbes as vital additives for solid waste composting. Heliyon 6(2):e03343. https:// doi.org/10.1016/j.heliyon.2020.e03343

19. de Araujo Avila GM, Gabardo G, Clock DC et al (2021) Use of efficient microorganisms in agriculture. Res. Soc Dev 10(8):e40610817515-e40610817515. https://doi.org/10.33448/ rsd-v10i8.17515

20. Villar I, Alves D, Garrido J et al (2016) Evolution of microbial dynamics during the maturation phase of the composting of different types of waste. Waste Manag 54:83-92. https://doi.org/10. 1016/j.wasman.2016.05.011

21. Lee Y (2016) Various microorganisms' roles in composting: a review. APEC Youth Sci J 8(1):11-15. http://amgs.or.kr/New/ common/journal/vol8/vol8_1_no.2.pdf. Accessed 18 Oct 2021

22. Leow CW, Van Fan Y, Chua LS et al (2018) A review on application of microorganisms for organic waste management. Chem Eng Trans 63:85-90. https://doi.org/10.3303/CET18 63015

23. Ke GR, Lai CM, Liu YY et al (2010) Inoculation of food waste with the thermo-tolerant lipolytic actinomycete Thermoactinomyces vulgaris A31 and maturity evaluation of the compost. Bioresour Technol 101(19):7424-7431. https://doi.org/10.1016/j. biortech.2010.04.051

24. Nakasaki K, Hirai H (2017) Temperature control strategy to enhance the activity of yeast inoculated into compost raw material for accelerated composting. Waste Manag 65:29-36. https:// doi.org/10.1016/j.wasman.2017.04.019

25. Karnchanawong S, Nissaikla S (2014) Effects of microbial inoculation on composting ofhousehold organic waste using passive aeration bin. Int J Recycl Org Waste Agric 3(4):113-119. https:// doi.org/10.1007/s40093-014-0072-0

26. Nakasaki K, Hirai H, Mimoto H et al (2019) Succession of microbial community during vigorous organic matter degradation in the primary fermentation stage of food waste composting. Sci Total Environ 671:1237-1244. https://doi.org/10.1016/j.scito tenv.2019.03.341

27. Xu J, Jiang Z, Li M et al (2019) A compost-derived thermophilic microbialconsortium enhances the humification process and alters the microbial diversity during composting. J Environ Manag 243:240-249. https://doi.org/10.1016/j.jenvman.2019.05. 008

28. Manu MK, Kumar R, Garg A (2017) Performance assessment of improved composting system for food waste with varying aeration and use of microbial inoculum. Bioresour Technol 234:167177. https://doi.org/10.1016/j.biortech.2017.03.023

29. Van Fan Y, Klemes JJ, Lee CT et al (2018) Efficiency of microbial inoculation for a cleaner composting technology. Clean Techn Environ Policy 20(3):517-527. https://doi.org/10.1007/ s10098-017-1439-5

30. Van Fan Y, Lee CT, Klemes et al (2018) Evaluation of Effective Microorganisms on home scale organic waste composting. J Environ Manag 216:41-48. https://doi.org/10.1016/j.jenvman. 2017.04.019

31. Voberkova S, Vaverkova MD, Buresova A et al (2017) Effect of inoculation with white-rot fungi and fungal consortium on the composting efficiency of municipal solid waste. Waste Manag 61:157-164. https://doi.org/10.1016/j.wasman.2016.12.039

32. Raju KV, Ravindra A, Manasi S et al (2018) Urban environmental governance in. Browsing Bengaluru. Springer, India

33. Xi BD, He XS, Wei ZM et al (2012) Effect of inoculation methods on the composting efficiency of municipal solid wastes. Chemosphere 88(6):744-750. https://doi.org/10.1016/j.chemosphere. 2012.04.032 
34. Awasthi MK, Pandey AK, Khan J et al (2014) Evaluation of thermophilic fungal consortium for organic municipal solid waste composting. Bioresour Technol 168:214-221. https://doi.org/10. 1016/j.biortech.2014.01.048

35. Kinet R, Destain J, Hiligsmann S et al (2015) Thermophilic and cellulolytic consortium isolated from composting plants improves anaerobic digestion of cellulosic biomass: toward a microbial resource management approach. Bioresour Technol 189:138-144. https://doi.org/10.1016/j.biortech.2015.04.010

36. Martínez-Valdez FJ, Martínez-Ramírez C, Martínez-Montiel L et al (2015) Rapid mineralisation of the organic fraction of municipal solid waste. Bioresour Technol 180:112-118. https:// doi.org/10.1016/j.biortech.2014.12.083

37. Li R, Wang Q, Zhang Z et al (2015) Nutrient transformation during aerobic composting of pig manure with biochar prepared at different temperatures. Environ Technol 36(7):815-826. https:// doi.org/10.1080/09593330.2014.963692

38. Hou N, Wen L, Cao H et al (2017) Role of psychrotrophic bacteria in organic domestic waste composting in cold regions of China. Bioresour Technol 236:20-28. https://doi.org/10.1016/j. biortech.2017.03.166

39. Heidarzadeh MH, Amani H, Javadian B (2019) Improving municipal solid waste compost process by cycle time reduction through inoculation of Aspergillus Niger. J Environ Health Sci Eng 17(1):295-303. https://doi.org/10.1007/s40201-019-00348-z

40. Liu J, Xu XH, Li HT et al (2011) Effect of microbiological inocula on chemical and physical properties and microbial community of cow manure compost. Biomass Energy 35:3433-3439. https://doi.org/10.1016/j.biombioe.2011.03.042

41. Pan I, Dam B, Sen SK (2012) Composting of common organic wastes using microbial inoculants. 3 Biotech 2:127-134. https:// doi.org/10.1007/s13205-011-0033-5

42. Chen G, Guan S, Zeng G et al (2013) Cadmium removal and 2,4-dichlorophenol degradation by immobilized Phanerochaete chrysosporium loaded with nitrogen-doped $\mathrm{TiO} 2$ nanoparticles. Appl Microbiol Biotechnol 97:3149-3157. https://doi.org/10. 1007/s00253-012-4121-1

43. Huang C, Zeng G, Huang D et al (2017) Effect of Phanerochaete chrysosporium inoculation on bacterial community and metal stabilization in lead-contaminated agricultural waste composting. Bioresour Technol 243:294-303. https://doi.org/10.1016/j.biort ech.2017.06.124

44. Siddiquee S, Shafawati SN, Naher L (2017) Effective composting of empty fruit bunches using potential Trichoderma strains. Biotechnol Rep 13:1-7. https://doi.org/10.1016/j.btre.2016.11. 001

45. Wang Y, Ai P (2016) Integrating particle physical geometry into composting degradation kinetics. Bioresour Technol 200:514520. https://doi.org/10.1016/j.apsusc.2016.07.073

46. Čater M, Fanedl L, Malovrh S et al (2015) Biogas production from brewery spent grain enhanced by bioaugmentation with hydrolytic anaerobic bacteria. Bioresour Technol 186:261-269. https://doi.org/10.1016/j.biortech.2015.03.029

47. Martin-Ryals A, Schideman L, Li P et al (2015) Improving anaerobic digestion of a cellulosic waste via routine bioaugmentation with cellulolytic microorganisms. Bioresour Technol 189:62-70. https://doi.org/10.1016/j.biortech.2015.03.069

48. Hua B, Dai J, Liu B et al (2016) Pretreatment of non-sterile, rotted silage maize straw by the microbial community MC1 increases biogas production. Bioresour Technol 216:699-705. https://doi.org/10.1016/j.biortech.2016.06.001

49. Zhang Q, He J, Tian M et al (2011) Enhancement of methane production from cassava residues by biological pretreatment using a constructed microbial consortium. Bioresour Technol 102(19):8899-8906. https://doi.org/10.1016/j.biortech.2011.06. 061
50. Poszytek K, Ciezkowska M, Sklodowska A et al (2016) Microbial consortium with high cellulolytic activity (MCHCA) for enhanced biogas production. Front Microbiol 7:324. https://doi. org/10.3389/fmicb.2016.00324

51. Gou C, Wang Y, Zhang X et al (2017) Inoculation with a psychrotrophic-thermophilic complex microbial agent accelerates onset and promotes maturity of dairy manure-rice straw composting under cold climate conditions. Bioresour Technol 243:339346. https://doi.org/10.1016/j.biortech.2017.06.097

52. Li J, Wang $X$, Cong $C$ et al (2020) Inoculation of cattle manure with microbial agents increases efficiency and promotes maturity in composting. 3Biotech 10(3):1-9. https://doi.org/10.1007/ s13205-020-2127-4

53. Wan L, Wang X, Cong C et al (2020) Effect of inoculating microorganisms in chicken manure composting with maize straw. Bioresour Technol 301:122730. https://doi.org/10.1016/j.biort ech. 2019.122730

54. Li W, Liu Y, Hou Q et al (2020) Lactobacillus plantarum improves the efficiency of sheep manure composting and the quality of the final product. Bioresour Technol 297:122456. https://doi.org/10.1016/j.biortech.2019.122456

55. Saha B, Saha S, Roy PD et al (2018) Microbial transformation of sulphur: an approach to combat the sulphur deficiencies in agricultural soils. In: Role of Rhizospheric Microbes in Soil. Springer, Singapore, pp 77-97

56. Luna MA, Mesa JR (2016) Microorganismos eficientes y sus beneficios para los agricultores. Rev Cient Agroecosist 4(2):31-40 http://aes.ucf.edu.cu/index.php/aes/index. Accessed 16 October 2021

57. Su P, Tan X, Li C et al (2017) Photosynthetic bacterium R hodopseudomonas palustris GJ-22 induces systemic resistance against viruses. Microb Biotechnol 10(3):612-624. https://doi.org/10. 1111/1751-7915.12704

58. Morocho T, Leiva-Mora (2019) Microorganismos eficientes, propiedades funcionales y aplicaciones agrícolas. Centro Agrícola 46(2):93-103 http://scielo.sld.cu/scielo.php?script=sci_artte xt\&pid=S0253-57852019000200093. Accessed 18 October 2021

59. Emprotec (2017) Guía de microorganismos eficaces. EM Producción y Tecnología S,A. http://www.infoagro.go.cr/Inforegiones/ RegionCentralOriental/Documents/Boletin\%20Tecnologia\%20\% 20EM.pdf. Accessed 16 October 2021

60. Souza RD, Ambrosini A, Passaglia LM (2015) Plant growthpromoting bacteria as inoculants in agricultural soils. Genet Mol Biol 38:401-419. https://doi.org/10.1590/S1415-4757384201 50053

61. Soto JA, Cárdenas JA, García JP (2017) Inoculation of substrate with lactic acid bacteria for the development of Moringa oleifera Lam plantlets. Cuba J Agric Sci 51(2). http://cjascience.com/ index.php/CJAS/article/view/733. Accessed 18 October 2021

62. Xu R, Zhang K, Liu P et al (2018) Lignin depolymerization and utilization by bacteria. Bioresour Technol 269:557-566. https:// doi.org/10.1016/j.biortech.2018.08.118

63. Londoño NA, Taborda MT, López CA et al (2015) Bacteriocinas producidas por bacterias ácido lácticas y su aplicación en la industria de alimentos. Alimentos Hoy 23(36):186-205 https://alimentoshoy.acta.org.co/index.php/hoy/article/view/356. Accessed 18 October 2021

64. Timmusk S, Nevo E, Ayele F et al (2020) Fighting Fusarium pathogens in the era of climate change: a conceptual approach. Pathogens 9(6):419. https://doi.org/10.3390/pathogens9060419

65. Beltrán TR, Campos CM (2016) Influencia de microorganismos eficaces sobre la calidad de agua y lodo residual, planta de tratamiento de Jauja. Thesis. Universidad Nacional del Centro del Perú. https://repositorio.uncp.edu.pe/bitstream/handle/20. 500.12894/3461/Beltran\%20Beltran-Campos\%20Rivero.pdf? sequence $=1$. Accessed 13 October 2021 
66. Fayemi OE, Ojokoh AO (2014) The Effect of different fermentation techniques on the nutritional quality of the cassava product (fufu). J Food Process Preserv 38(1):183-192

67. Meena SK, Meena VS (2017) Importance of soil microbes in nutrient use efficiency and sustainable food production. In: Agriculturally Important Microbes for Sustainable Agriculture. Springer, Singapore, pp 3-23

68. Farrag HM, Bakr AA (2021) Biological reclamation of a calcareous sandy soil with improving wheat growth using farmyard manure, acid producing bacteria and yeast. SVU-Int J Agric Sci 3(1):53-71. https://doi.org/10.21608/SVUIJAS.2021.57919.1070

69. Vurukonda SSKP, Giovanardi D, Stefani E (2018) Plant growth promoting and biocontrol activity of Streptomyces spp. as endophytes. Int J Mol Sci 19(4):952. https://doi.org/10.3390/ijms1 9040952

70. Chaurasia A, Meena BR, Tripathi AN et al (2018) Actinomycetes: an unexplored microorganisms for plant growth promotion and biocontrol in vegetable crops. World $\mathrm{J}$ Microbiol Biotechnol 34(9):1-16. https://doi.org/10.1007/ s11274-018-2517-5

71. Kausar H, Sariah M, Mohd H et al (2011) Isolation and screening of potential actinobacteria for rapid composting of rice straw. Biodegradation 22:367-375. https://doi.org/10.1007/ s10532-010-9407-3

72. Yang Z, Jiang Z, Hse CY et al (2017) Assessing the impact of wood decay fungi on the modulus of elasticity of slash pine (Pinus elliottii) by stress wave non-destructive testing. Int Biodeterior Biodegradation 117:123-127. https://doi.org/10.1016/j. ibiod.2016.12.003

73. El-Gendy MMA, Al-Zahrani SHM, El-Bondkly AMA (2017) Construction of potent recombinant strain through intergeneric protoplast fusion in endophytic fungi for anticancerous enzymes production using rice straw. Appl Biochem Biotechnol 183(1):30-50. https://doi.org/10.1007/s12010-017-2429-0

74. Horwath WR (2017) The role of the soil microbial biomass in cycling nutrients. In: Tate KR (ed) Microbial Biomass: A Paradigm Shift in Terrestrial Biogeochemistry. World Scientific, New Jersey, pp 41-66

75. Romero TDJ, Vargas D (2017) Uso de microorganismos eficientes para tratar aguas contaminadas. Rev Cient Ing Hidrául Ambient 38(3):88-100 http://scielo.sld.cu/scielo.php?script= sci_arttext\&pid $=$ S1680-03382017000300008. Accessed 18 October 2021

76. Ramírez MA (2009) Tecnología de microorganismos efectivos (EM) aplicada a la agricultura y medio ambiente sostenible. Tesis de Ingeniería Ambiental. Universidad Industrial de Santander

77. Sánchez ÓJ, Ospina DA, Montoya S (2017) Compost supplementation with nutrients and microorganisms in composting process. Waste Manag 69:136-153. https://doi.org/10.1016/j.wasman. 2017.08.012

78. Hamad MA, Hussein SA, Mahmmoud EN et al (2020) The inhibitory role of effective microorganisms on the growth of pathogenic bacteria. Iraqi J Vet Sci 34(1):153-158. https://doi.org/10. 33899/ijvs.2019.125653.1123

79. Safwat SM, Rozaik E (2018) Growth inhibition of various pathogenic microorganisms using effective microorganisms (EM). Inter J Res Eng 4(12):283-286. https://doi.org/10.21276/ijre. 2017.4.12.2

80. Rahman S, Siddique M, Hussain T et al (1999) An in vitro antibacterial activity of different effective microorganism cultures against pathogenic species. Pak J Biol Sci 2(1):214-216. https:// doi.org/10.3923/pjbs.1999.214.216

81. Jwher DM (2014) Effects of feeding effective microorganisms on blood levels of antibodies to Newcastle disease virus vaccine and trace element in broiler chicks. Assiut Vet Med J 6(141):38-44. https://doi.org/10.33899/ijvs.2013.82784
82. Esatu W, Terefe G, Dessie T (2012) Immunomodulatory effect of effective microorganisms (EM) in chickens. Res J Immunol 5(1):17-23. https://doi.org/10.3923/rji.2012.17.23

83. García-Velázquez L, Gallardo A (2017) El ciclo global del nitrógeno. Una visión para el ecólogo terrestre. Ecosistemas 26(1):4-6. https://doi.org/10.7818/ECOS.2017.26-1.02

84. Grajo MRD, Villegas LC, Montecillo AD et al (2017) Effect of organic fertilizer amina $\mathrm{P}$ on the yield of pineapple (Ananas comosus L.) Merr. and soil microbial population. Philipp Agric Sci 100:12-20 https://www.researchgate.net/profile/AndrewMontecillo/publication/318208995. Accessed 19 October 2021

85. Kakraliya M, Singh R (2018) Effect of soil test crop response basis integrated nitrogen management on yield, quality and profitability of wheat (Triticum aestivum L.). J Pharmacogn Phytochem 7(4):532-534 https://www.phytojournal.com/archives/ 2018/vol7issue4/PartI/7-3-618-519.pdf. Accessed 19 October 2021

86. Poveda J, Abril-Urias P, Escobar C (2020) Biological control of plant-parasitic nematodes by filamentous fungi inducers of resistance: Trichoderma, mycorrhizal and endophytic fungi. Front Microbiol 11:992. https://doi.org/10.3389/fmicb.2020.00992

87. Schlatter D, Kinkel L, Thomashow L et al (2017) Disease suppressive soils: new insights from the soil microbiome. Phytopathology 107(11):1284-1297. https://doi.org/10.1094/ PHYTO-03-17-0111-RVW

88. Schnürer J, Magnusson J (2005) Antifungal lactic acid bacteria as biopreservatives. Trends Food Sci Technol 16(1-3):70-78. https://doi.org/10.1016/j.tifs.2004.02.014

89. Satyaprakash M, Nikitha T, Reddi EUB et al (2017) Phosphorous and phosphate solubilising bacteria and their role in plant nutrition. Int J Curr Microbiol App Sci 6(4):2133-2144. https://doi. org/10.20546/ijcmas.2017.604.251

90. Joshi H, Somduttand CP, Mundra SL (2019) Role of effective microorganisms (EM) in sustainable agriculture. Int J Curr Microbiol App Sci 8(3):172-181. https://doi.org/10.20546/ijcmas.2019.803.024

91. Ncube L (2008) Evaluation of effective micro-organisms (EM) on soil chemical properties and yield of selected vegetables in the Eastern Cape, South Africa (Doctoral dissertation, University of Fort Hare). https://core.ac.uk/download/pdf/145043267.pdf. Accessed 18 October 2021

92. Khaliq A, Abbasi MK, Hussain T (2006) Effects of integrated use of organic and inorganic nutrient sources with effective microorganisms (EM) on seed cotton yield in Pakistan. Bioresour Technol 97(8):967-972. https://doi.org/10.1016/j.biortech.2005.05. 002

93. Singh G, Shamsuddin MR, Lim SW (2018) Characterization of chicken manure from manjung region. In: In IOP Conference Series: Materials Science and Engineering, 458th edn. IOP Publishing, Bristol, p 012084

94. Liu H, Huang Y, Duan W et al (2020) Microbial community composition turnover and function in the mesophilic phase predetermine chicken manure composting efficiency. Bioresour Technol 313:123658. https://doi.org/10.1016/j.biortech.2020.123658

95. Li S, Li J, Yuan J et al (2017) The influences of inoculants from municipal sludge and solid waste on compost stability, maturity and enzyme activities during chicken manure composting. Environ Technol 38(13-14):1770-1778. https://doi.org/10.1080/ 09593330.2017 .1291755

96. Hidalgo D, Corona F, Martín-Marroquín J (2021) Effect of effective microorganisms on poultry, cattle and pig manure. In: CHISA 2021 virtual proceedings

97. Gunawan VC, Bin Shamsuddin MR, Bin Mat Isa NH et al (2020) Performance analysis of effective microorganisms on chicken manure composting. Sci Eng Health Stud 14(2):132-140. https:// doi.org/10.14456/sehs.2020.12 
98. Joseph A, Ademiluyi BO, Aluko PA et al (2016) Effect of poultry manure treated and untreated with effective microorganisms on growth performance and insect pest infestation on Amaranthus hybridus. African J Plant Sci 10(1):10-15. https://doi.org/10. 5897/AJPS2015.1364

99. Reddy LN, Giller KE (2008) How effective are effective microorganisms. LEISA Mag 24:18-19 https://edepot.wur.nl/60561. Accessed 26 October 2021

100. Uribe JF, Estrada MM, Córdoba S et al (2001) Evaluación de los microorganismos eficaces (EM) en producción de abono orgánico a partir del estiércol de aves de jaula. Rev Colomb Cienc Pecu 14(2):164-172 https://revistas.udea.edu.co/index. $\mathrm{php} / \mathrm{rccp} /$ article/view/323763. Accessed 26 October 2021

101. Ge M, Zhou H, Shen Y et al (2020) Effect of aeration rates on enzymatic activity and bacterial community succession during cattle manure composting. Bioresour Technol 304:122928. https://doi.org/10.1016/j.biortech.2020.122928

102. Li J, Wang X, Cong C et al (2020) Inoculation of cattle manure with microbial agents increases efficiency and promotes maturity in composting. 3. Biotech 10(3):1-9. https://doi.org/10.1007/ s13205-020-2127-4

103. Xi B, He X, Dang Q et al (2015) Effect of multi-stage inoculation on the bacterial and fungal community structure during organic municipal solid wastes composting. Bioresour Technol 196:399-405. https://doi.org/10.1016/j.biortech.2015.07.069

104. Jiang J, Liu X, Huang Y et al (2015) Inoculation with nitrogen turnover bacterial agent appropriately increasing nitrogen and promoting maturity in pig manure composting. Waste Manag 39:78-85. https://doi.org/10.1016/j.wasman.2015.02.025

105. Zhao Y, Lu Q, Wei Y et al (2016) Effect of actinobacteria agent inoculation methods on cellulose degradation during composting based on redundancy analysis. Bioresour Technol 219:196-203. https://doi.org/10.1016/j.biortech.2016.07.117

106. Nakasaki K, Araya S, Mimoto H (2013) Inoculation of Pichia kudriavzevii RB1 degrades the organic acids present in raw compost material and accelerates composting. Bioresour Technol 144:521-528. https://doi.org/10.1016/j.biortech.2013.07.005
107. Mouhamad RS, Mohammed ZJ, Abdulhadi AA et al (2020) Production and characterization of organic manure from liquorice residues. Inf Process Agri 7(2):233-241. https://doi.org/10. 1016/j.inpa.2019.09.004

108. Zhou H, Shen Y, Li R et al (2020) Heavy metals and community structure of microorganism changes during livestock manure composting with inoculation of effective microorganisms. Int $\mathbf{J}$ Agric Biol Eng 13(6):125-132. https://doi.org/10.25165/j.ijabe. 20201306.5674

109. Li R, Meng H, Zhao L et al (2019) Study of the morphological changes of copper and zinc during pig manure composting with addition of biochar and a microbial agent. Bioresour Technol 291:121752. https://doi.org/10.1016/j.biortech.2019.121752

110. Xu P, Li J (2017) Effects of microbial inoculant on physical and chemical properties in pig manure composting. Compost Sci Util 25(sup1):S37-S42. https://doi.org/10.1080/1065657X.2017. 1295886

111. Bastami MSB, Jones DL, Chadwick DR (2016) Reduction of methane emission during slurry storage by the addition of effective microorganisms and excessive carbon source from brewing sugar. J Environ Qual 45(6):2016-2022. https://doi.org/10.2134/ jeq2015.11.0568

112. Joung-Soo L, Cho SB, Han DW et al (2015) Removal of ammonia from swine manure by mixed microorganisms. Korea Waste Resources Circ Soc 2015:381-384 https://papersearch.net/thesis/ article. asp?key $=3686365$

113. Hu T, Wang X, Zhen L et al (2019) Effects of inoculation with lignocellulose-degrading microorganisms on antibiotic resistance genes and the bacterial community during co-composting of swine manure with spent mushroom substrate. Environ Pollut 252:110-118. https://doi.org/10.1016/j.envpol.2019.05.078 Accessed 27 October 2021

Publisher's Note Springer Nature remains neutral with regard to jurisdictional claims in published maps and institutional affiliations. 